Article

\title{
Depictions of American Indians in George Armstrong Custer's My Life on the Plains
}

\author{
Danielle Johannesen \\ Department of Liberal Arts \& Education, University of Minnesota Crookston, Crookston, MN 56716, USA; \\ johan259@crk.umn.edu
}

Received: 8 February 2019; Accepted: 10 March 2019; Published: 14 March 2019

\begin{abstract}
General George Armstrong Custer remains one of the most iconic and mythologized figures in the history of the American West. His infamous defeat at the 1876 Battle of the Little Bighorn largely defines his legacy; historical scholarship and popular representations of Custer consistently focus on his "Last Stand." However, Custer was also a writer with a keen appreciation for arts and culture. This article analyzes Custer's descriptions of American Indians in his memoir My Life on the Plains (1874). I trace how Custer's descriptions of Indians and Indian culture clearly reveal a colonial mindset; yet, Custer regularly reflects on Indians and Indian culture with interest, curiosity, and even respect. I analyze these moments of potential commiseration and question whether these moments depart from a colonial mindset. Additionally, I analyze how Custer constructs Indians as the "enemy" and show how these constructions are problematic, yet critical for Custer's aestheticizing of military conflict. Ultimately, I argue that Custer's memoir is deserving of increased attention as a literary text and show how to reveal complexities and contradictions with literary and historical implications.
\end{abstract}

Keywords: Indian Wars; George Armstrong Custer; war narratives; colonialism; settler-colonialism; Western American literature; frontier literature

War narratives are an important part of world and American history. From a literary perspective, war narratives are powerful in their engagement with historical events of the utmost dramatic magnitude. War is an arena where questions of mortality, comradery, heroism, and humanity are situated within complex sociopolitical contexts and global power structures. War is often defined by an overarching story founded on a basic dramatic premise where a protagonist battles an antagonist as a way to resolve political conflict. Of course, war is sometimes perpetuated upon participants who are subsequently forced to defend themselves against foreign invaders or external threats. For example, when used as an arm of colonialism, war typically involves the conquest of indigenous lands; this conquest is often justified by an overarching narrative pitting European conquerors and settlers as civilized and aligned with God against indigenous peoples characterized as uncivilized and savage (Callahan et al. 2006, p. 556). Colonialism depends on the construction of a war narrative wherein an antagonistic enemy must be defeated in the name of civilization. The North American Indian Wars were perpetuated by colonial, governmental, and military forces inspired by this very logic.

As one of the most iconic and mythologized figures in the history of the American West, General George Armstrong Custer was a major participant in the North American Indian Wars. His infamous defeat at the 1876 Battle of the Little Bighorn largely defines his legacy; historical scholarship and popular representations of Custer consistently focus on his "Last Stand". However, Custer was also a writer with a keen appreciation for arts and culture. Beginning in 1872, Custer began publishing accounts of his frontier experiences in The Galaxy, a magazine "which contained better-class fiction along with articles dealing with history and biography and some verse" (Custer [1874] 1976, p. xxiii). These accounts were collected and published in 1874 as My Life on the Plains, or Personal Experiences 
with Indians. Custer's My Life on the Plains is a war narrative. The memoir not only includes Custer's accounts of actual armed conflicts, including the Battle of the Washita, but the book also reflects how the Indian Wars more broadly hinged on depictions of Indians as the cultural enemy of white Europeans. Custer's memoir provides a powerful example of a soldier reflecting on cultural differences as a way to justify war. The complex and often contradictory depictions of Indians and Indian culture throughout My Life on the Plains have literary and historical implications in terms of how scholars and students reflect on Custer's legacy and the broader history of the American West.

While Custer's descriptions clearly reflect a colonialist mindset, depictions of Indians as the violent, "savage" enemy are sporadically countered with passages where Custer reveals an interest in and respect for Indians and Indian culture. Custer's reflections reveal curiosity and interest in Indian culture and an appreciation for Indians as necessary actors in the theater of war. Additionally, brief moments emerge in My Life on the Plains where Custer arguably commiserates with Indians. This article analyzes how Custer expresses curiosity in and appreciation for Indians and questions the implications of brief commiserations with Indians. Further, this article shows how curiosity in and descriptions of the indigenous "enemy" are difficult to separate from colonialist ideology. Ultimately, despite an apparent interest in Indian life and a complex and often contradictory attitude toward Indians, Custer's memoir fails to reveal a genuine sense of justice or mercy toward Indians who continue to resist colonization.

Custer had lofty ambitions in all areas of his life. While renowned for his military achievements and exploits, Custer also aspired to gain respect as an intellectual. Although Custer was unremarkable as a student at West Point, he possessed a keen interest in culture, history, and the arts. Custer greatly enjoyed New York City, frequenting the theater and engaging with newspaper reporters and editors, several of whom expressed interest in his talents as a writer (Stiles 2016, pp. 419-20). As Edgar I. Stewart writes in his introduction to My Life on the Plains, "Custer had always been interested in writing, and although he had been nothing better than an average student at the Military Academy ... he developed into a serious student after the close of the Civil War, very likely through the influence of his wife, Elizabeth Bacon Custer. His special interests were history and literature" (Custer [1874] 1976, p. xxiii). Custer also wrote articles for Turf, Field and Farm magazine, which were published between 1871-1873 (Stiles 2016, p. 365). Additionally, Custer's letters to his wife, Libbie, are often quoted and studied for their descriptions of Custer's military and frontier exploits and for their intimate personal reflections. Custer's letters offer firsthand documentation of Civil War and frontier history as well as detailed accounts of a marriage situated in the context of some of the most significant historical events in American history. My Life on the Plains is, therefore, an important text, both for its engagement with frontier history and as an example of Custer's literary abilities. Although opinions differ as to the literary quality of Custer's writing, the memoir aspires to be a respected literary text.

Custer immediately puts his memoir in conversation with literary depictions of Indians and Indian life. Early in the memoir, Custer expresses a desire to counter inaccurate and romanticized depictions of Indians such as those found in the works of novelist James Fenimore Cooper. Custer writes,

Stripped of the beautiful romance with which we have been so long willing to envelope him, transferred from the inviting pages of the novelist to the localities where we are compelled to meet with him, in his native village, on the war path, and when raiding upon our frontier settlements and lines of travel, the Indian forfeits his claim to the appellation of the "noble red man". (Custer [1874] 1976), p. 13)

The implication is that Custer's firsthand experiences, which he goes on to document in the memoir, provide a more realistic and accurate record of Indian life than what might be found in "the inviting pages of the novelist." Specifically, the passage shows Custer's desire to counter depictions of Indians as "noble savages". Custer attempts to strip the idea of "nobility" from the Indian and implies that the reality of what he terms the "Indian character" (Custer [1874] 1976, p. 19) coincides with a serious threat to settlement and civilization. Throughout his memoir, Custer consistently describes Indians as savage, violent, and uncivilized. Establishing Indians as "savage" and impossible to civilize is 
central to Custer's construction of Indians as the "enemy". Custer regularly describes Indians as "infesting" the landscapes and territories of the American West. He uses similarly dehumanizing terminology throughout the book, describing Indians as "the most cruel, heartless, and barbarous of human enemies" (Custer [1874] 1976, p. 274) and later notes the "red man's bloodthirsty and insatiable vengeance" (Custer [1874] 1976, p. 289). These types of descriptions, which permeate the memoir, serve as simplistic generalizations seemingly aimed at providing evidence of the threats Indians posed to white settlers as they moved into the lands west of the Mississippi River. Those Indians who resisted moving to the reservations were viewed as especially dangerous (Kreyche 1994, p. 89), and this view is reflected in Custer's memoir.

Custer's depictions of Indians as the barbarous and uncivilized enemy reflect an obvious and predictable colonial mindset. It is important to note that the memoir participates in and encourages what Dunbar-Ortiz (2014) terms the "settler-colonialist context of US history" (p. 6). According to Custer, Indians who continued to resist reservation life-those who continued to fight for their lands and traditional ways of life-posed the most serious threat to white settlement; this Indian resistance necessitated the Indian Wars. Configuring those Indians as the "hostile enemy" surfaces as an important element of Custer's logic, and of the broader logic of settler-colonialism, which Cox (2017) defines as "an ongoing system of power that perpetuates the genocide and repression of indigenous peoples and cultures. Essentially hegemonic in scope, settler-colonialism normalizes the continuous settler occupation, exploiting lands and resources to which indigenous peoples have genealogical relationships." The memoir establishes a spectrum of sorts where "peaceful" Indians who acquiesce to the government's demands by moving to the reservations are essentially harmless, whereas those Indians who continue to resist must be defeated in order to enable white settlement. In many ways, the memoir reveals how Indians are defined as the "enemy" largely because their ways of life did not conform or cater to the logic of white supremacy.

Although Custer's memoir clearly reflects a racist and hegemonic ideology rooted in settler-colonialism, My Life on the Plains includes many passages and reflections where Custer expresses keen curiosity and interest in Indian life. The most well-known of these passages appears early in the memoir where Custer reflects on the lives of reservation Indians as compared to those who remain "free": "If I were an Indian, I often think I would greatly prefer to cast my lot among those of my people adhered to the free open plains rather than submit to the confined limits of a reservation, there to be the recipient of the blessed benefits of civilization, with its vices thrown in without stint or measure" (Custer [1874] 1976, p. 22). Interestingly, this passage reveals a brief moment where Custer questions the supremacy of civilization, romanticizing the "free open plains" as preferable to the "confined limits" of a reservation. Custer further reflects on how Indians do not, realistically, have the ability to control their own destinies. He notes that Indians can act and behave in ways as long as their actions do not "run contrary to the requirements of civilization in its advancing tread" (Custer [1874] 1976, p. 22). This passage shows Custer's awareness of the inevitability of white settlement and of the destruction of indigenous autonomy. Of this inevitability, Custer goes on to write, "Destiny seems to have willed it, and the world looks on and nods its approval" (Custer [1874] 1976, p. 23). These passages expose a potential contradiction underlying Custer's construction of Indians as the enemy. On one hand, Custer consistently portrays hostile Indians as dangerous foes who must be eliminated by means of warfare. Conversely, the passages quoted above reveal how Custer views the defeat of the Indians as inevitable, with the forces bringing about this defeat being "destiny" and the "requirements of civilization" rather than military force. This is important because it exposes a point where Custer falls short of genuine commiseration; although he seems to understand why Indians would resist colonization in favor of the "free open plains", at no point does this understanding cause him to question his own actions as a military officer.

Custer reveals great curiosity and interest regarding Indians and Indian culture. Throughout My Life on the Plains, Custer regularly uses the words "interest" and "interesting" when reflecting on Indian culture. Early in the book, Custer writes, "In studying the Indian character, while shocked 
and disgusted by many of his traits and customs, I find much to be admired and still more of deep and unvarying interest. To me, Indian life, with its attendant ceremonies, mysteries, and forms, is a book of unceasing interest" (Custer [1874] 1976, p. 19). Given Custer's interest in writing and literary culture, his use of the book metaphor as a way to describe Indian life is notable. The book metaphor suggests that Indians are an object to be read, studied, and analyzed; in comparing Indians to an object, Custer further dehumanizes Indians. The passage also suggests that Indian life is exotic-in noting the "mysteries" of Indian life, Custer reveals how he perceives Indian life as substantially different from his own cultural practices as a white American. In many ways, Custer situates himself as an ethnographer with firsthand experience of Indians and Indian culture that he then relays to readers throughout his memoir. In addition to the passage quoted above, in which Custer expresses that he more closely identifies with Indians "adhered to the free open plains", Custer frequently reflects on, describes, and arguably commiserates with Indians throughout his book in ways that seem to contradict the simplistic, colonialist ideology underlying Westward expansion. As Cozzens (2016) argues, oversimplifications of complex historical circumstances have come to define how many citizens and academics understand the Indian Wars and Westward expansion more broadly. While Custer's memoir consistently reflects racist and colonialist ideology, oversimplifying Custer's perspectives compromises the pursuit of a comprehensive understanding of both history and narrative. As Utley and Washburn write, accounts of the Indian Wars that aim to document the Indian perspective sometimes produce unbalanced accounts that assume a simplistic division between whites as "exploitative conquerors" (Utley and Washburn [1977] 2002, p. vi) and Indians as "romantic, innocent victims" (p. vi). Paradoxically, Custer both participates in the displacement of Indian culture while simultaneously documenting what he terms the "wonderful and peculiar powers of the Indian" (Custer [1874] 1976). Analyzing Custer's mixed and often contradictory descriptions of his "enemy" is therefore an important aspect of understanding historical events and reflects how "the government's response to the 'Indian problem' was inconsistent" (Cozzens 2016, p. 8).

Much of the Custer's content regarding Indian life engages in "thick description" (Mueller 2017) typical of ethnography. Like an ethnographer, Custer regularly documents his observations of Indian life as a way to provide readers with insight into Indian culture. Many of these descriptions focus on elements of Indian culture, including warfare and battle strategies, burial practices, oratorical skills, horsemanship, and dress. For example, Custer describes the contents of an empty Indian lodge that "the Indians had fled before the arrival of the cavalry" (Custer [1874] 1976, p. 40). Throughout this passage, Custer employs a seemingly objective tone in documenting the contents of the lodge, describing the contents as "the usual adornments and articles which constitute the household effects of an Indian family" (Custer [1874] 1976, p. 40). In describing the contents of the lodge, Custer makes clear that the scene is essentially "undisturbed" and provides a glimpse into the everyday domestic practices of Indians. Custer observes buffalo robes, doormats, rawhide ropes, paint bags, and "the decaying embers of a small fire built in the center" (Custer [1874] 1976, p. 40). Custer is not alone in exploring the lodge and describes entering the lodge with a doctor from the cavalry. A camp kettle hangs over the fire, and Custer details the doctor's interest in the contents of the kettle: "The doctor, ever on the alert to discover additional items of knowledge, whether pertaining to history or science, snuffed the savory odors which arose from the dark recesses of the mysterious kettle" (Custer [1874] 1976, p. 40). Custer's language situates the doctor as a curious investigator with an interest in Indian life. Custer describes the doctor using a horn spoon to sample the contents of the kettle and notes that the doctor's reaction was one of disgust upon realizing the food in the kettle is dog meat (Custer [1874] 1976, p. 41). The passage also reveals a theme present throughout the memoir: Indian life is consistently depicted as mysterious and ultimately unknowable. Early in the memoir, Custer shares his belief that Indian life is "unknowable" to the white man: "I know that all tribes with which I have been brought in contact carry with them a mysterious something which is regarded with the utmost sacredness and veneration, and upon which the eye of no white man at least is ever permitted to rest" (Custer [1874] 1976, p. 17). 
On the surface, these passages seem to reveal Custer's genuine curiosity and interest in Indian life. However, curiosity and interest in the culture of the "other" - even if that interest is genuine-are difficult to separate from the broader forces of colonialism. While Custer configures himself and the doctor as participant-observers, the act of entering the lodge symbolizes the dynamic of colonial conquest underlying Custer's work. In entering and describing the lodge, Custer and the doctor express interest in Indian life while simultaneously invading and occupying an Indian domicile. Custer's interest in Indian life cannot be separated from colonialism. In fact, as Loomba (2005) explains, learning about indigenous peoples and gathering knowledge about their ways of life is an element of colonialism: "No branch of learning was left untouched by the colonial experience. A crucial aspect of this process was the gathering and ordering of information about the lands and peoples visited by, and later subject to, the colonial powers" (p. 53). Many narratives of "first contact" and colonialism present stories about indigenous cultures relayed through the perspective of the colonizer. Curiosity and interest in Indian life is therefore not a departure from the colonial mindset but rather a central means through which colonizers craft and control constructions of the "other" (Loomba 2005, pp. 53-56).

Constructions of Indians as "other" stem not only from Custer's perceptions of Indian life and culture but also from his contextualization of colonialism as warfare. In many ways, Custer imagines the Indian Wars as a kind of theatrical performance of warfare where an "other"- the enemy-is critical. As mentioned above, Custer is simultaneously aware of the inevitable defeat of hostile Indians yet engaged in a fantasy of warfare within which Indians must function as a formidable foe. Custer aestheticizes warfare, regularly describing military engagements in terms of beauty. In one passage, Custer describes forming a circle of troops around an Indian village, explaining that the elements of the scene "all combined to produce an artistic effect, as beautiful as it was interesting" (Custer [1874] 1976, p. 38). For Custer, warfare and the dynamic between the military and its enemy present dramatic scenes not unlike those Custer enjoyed when frequenting the theater in New York City. In one passage, Custer describes an Indian battle line as "one of the finest and most imposing military displays ... which it has ever been my lot to behold" (Custer [1874] 1976, p. 32). In describing the weapons displayed by the Indians, Custer goes on to note, with sarcasm, the "strong love of fair play which prevails in the Indian Department" and the "wonderful liberality of our government, which not only is able to furnish its soldiers with the latest improved style of breechloaders to defend it and themselves, but is equally able and willing to give the same pattern of arms to their common foe" (p. 33). Tinged with sarcasm, this passage reveals "fair play" as a kind of fantasy contributing to the justification of colonialism. For example, the 1890 Wounded Knee Massacre was initially labeled a "battle," despite the fact that the disarmed Lakota were essentially defenseless with many women and children gunned down as they tried to flee to safety (Dunbar-Ortiz 2014, p. 155). Imagining an unfair conflict as an epic military battle is typical of Eurocentric historical narratives, and Custer's ambivalent attitude toward genuine justice reflects an awareness of the theatrical narrative typically used to justify colonialism.

Indian warriors undoubtedly possessed strength, ability, and determination, as evidenced by Custer's defeat at the Battle of the Little Bighorn. However, Custer's characterization of Indians as "hostile enemies" who posed a legitimate threat to the inevitable settling of the American West is problematic. As Brown explains in Bury My Heart at Wounded Knee: An Indian History of the American West, the United States federal government used the doctrine of Manifest Destiny to justify the total domination of Indians and their lands. Brown writes of Europeans, "They were the dominant race and therefore responsible for the Indians-along with their lands, their forests, and their mineral wealth" (Brown [1970] 2007, p. 8). While Custer's memoir reflects how Eurocentric and governmental narratives of the Indian Wars attempted to frame colonization as a "battle" between two equal foes, the idea that Indians could prevent or defeat the settlement of the West spurred by Manifest Destiny is inaccurate. Indeed, the arrival of Europeans to the New World brought with it multiple threats that Indians were powerless to counter or influence. These threats included not only disease but also 
"European powers pitting one Indigenous nation against another or factions within nations, with European allies aiding one or both sides" (Dunbar-Ortiz 2014, pp. 40-41). Custer describes the "hostile enemy" as not only posing a threat to settlers and the military, but also as threatening those Indians who had resigned themselves to reservation life. In describing the need to ally with reservation Indians, Custer writes,

The tribes against which we proposed to operate during the approaching campaign had been particularly cruel and relentless in their wanton attacks upon the Osages and Kaws, two tribes living peaceably and contentedly on well-chosen reservations in southwestern Kansas and the northern portion of the Indian Territory. No assistance in fighting the hostile tribes was desired, but it was believed, and correctly too, that in finding the enemy and discovering the location of his winter hiding places, the experience and natural tact and cunning of the Indians would be a powerful auxiliary if we could enlist them in our cause. (Custer [1874] 1976, p. 209)

This passage exemplifies the complexities of Custer's descriptive engagement with Indians as "enemy". While he clearly uses a racist logic when describing Indians as savage and uncivilized, those Indians who have acquiesced to reservation life and by extension Manifest Destiny are imagined as potential allies.

While Custer regularly describes elements of Indian culture, he also recounts key moments where he participates in Indian cultural practices. Most notable is Custer's story about participating in a peace pipe ceremony with a group of Indian chiefs. Custer describes visiting the lodge of Cheyenne chief Medicine Arrows, a relative of Black Kettle, a Cheyenne leader killed by Custer's 7th Cavalry during the Battle of the Washita. Once inside the lodge, Custer observes a medicine man facilitating a ceremony during which he (the medicine man) offers the pipe to Custer. Of being invited to smoke, Custer writes, "A desire to conform as far as practicable to the wishes of the Indians, and a curiosity to study a new and interesting phase of the Indian character, prompted me to obey the direction of the medicine man, and I accordingly began puffing away with as great a degree of nonchalance as a man unaccustomed to smoking could well assume" (Custer [1874] 1976, p. 357). Again, Custer expresses curiosity and a desire to learn about Indian cultural practices. However, this passage also reveals a desire to "conform," to some extent, to the "wishes of the Indians". Custer also yields to "the direction of the medicine man," which indicates a subtle shift in the power dynamic with Custer assuming a subservient role, if only briefly.

Importantly, the peace pipe ceremony is facilitated by the Indian chiefs as a way to broker a peace agreement with Custer. Custer explains that following the peace pipe ceremony, he agrees to a kind of peace pact with the chiefs: "I became for the time being an ardent advocate of peace measures, and informed the chiefs that such was my purpose at the time" (Custer [1874] 1976, p. 358). Custer's use of "for the time being" reflects that his interest in peace was temporary and likely disingenuous. However, Custer's memoir fails to mention a key element of the peace pipe ceremony as remembered from the Cheyenne perspective. Stiles (2016) describes the peace pipe ceremony as follows: "A ritual pipe was prepared, given to Custer to smoke, then passed around; a Cheyenne report claims that the ashes were dumped out on Custer's boots to curse him" (p. 322). Although it remains impossible to confirm every detail surrounding the peace pipe ceremony, these conflicting stories serve as a reminder that Custer's memoir is incapable of achieving a historical record that reflects the Indian perspective.

The peace pipe ceremony emerges as an opportunity for commiseration where Custer ultimately falls short. Following what Stiles (2016) calls "complicated negotiations" (323) regarding the desired release of two white women being held captive by the Cheyenne, Custer captures three Cheyenne leaders and threatens their lives. Stiles (2016) explains, "He [Custer] showed them the tree where he would hang them, so there would be no misunderstanding. After he executed them, he planned to assault the village" (p. 323). Custer's mission to convince the Cheyennes to surrender to the army lasts for several months, ultimately culminating as "Maj. Eugene Carr led the 5th Cavalry and a detachment of Pawnee scouts in a surprise attack on their [the Cheyennes and allies] camp near 
Summit Springs in the Colorado Territory. They killed the famous Tall Bull along with scores of men, women, and children" (Stiles 2016, p. 323). During the peace pipe ritual, Custer performs an act of commiseration as part of an overarching colonial strategy. Custer is willing to act peaceably and sympathetically toward Indians who comply with his demands, such as reservation Indians. Those Indians who continue to resist, or who fail to meet Custer's demands, remain squarely in the position of an enemy that must be destroyed in the pursuit of settlement.

Arguably, one passage in My Life on the Plains reveals a moment of clear commiseration. This passage appears following Custer's discussion of the Indians' impressive horsemanship skills. Throughout out the memoir, Custer documents his impressions of Indian horsemanship, writing, "Surely no race of men, not even the famous Cossacks, could display more wonderful skills in feats of horsemanship than the Indian warrior on his native plains" (Custer [1874] 1976, p. 199). Custer goes on to describe an Indian warrior thrown from his pony who seemed fated to capture by the cavalry. Custer describes how "comrades of the fallen Indian" (Custer [1874] 1976, p. 201) rushed to his aid with the group of Indians ultimately escaping the cavalry's pursuit. Custer further expresses relief at the Indian's escape:

Although chagrined at the failure of the pursuing party to accomplish the capture of the Indians, I could not wholly suppress a feeling of satisfaction, if not gladness, that for once the Indian had eluded the white man. I need not add that any temporary tenderness of feeling toward the two Indians was prompted by their individual daring and the heroic display of comradeship in the successful attempt to render assistance to a friend in need. (Custer [1874] 1976, p. 201)

In this passage, perhaps more than any other in his memoir, Custer expresses a sense of happiness at seeing Indians escape the cavalry. In writing that he "could not wholly suppress" this sense of happiness, Custer suggests a lack of control over his own feelings. He seems to experience a genuine, instinctual sense of kinship with the Indians, as he admires their bravery and comradeship-certainly, these are shared values among tribal warriors and the United States Army. However, Custer remains distanced from the Indian warriors. He admires their bravery within a battle scene, of sorts, but he does not reveal any awareness of the Indians as complex humans with whom he might want to learn from or forge a relationship. Custer's language is also careful to emphasize the rarity and transience of his feelings of commiseration toward Indians. In describing his tenderness as "temporary", and in using the language "for once", Custer emphasizes that his feelings are fleeting and that the Indian's escape is an exception rather than the rule. At no point does Custer feel truly threatened by the prospect of a grand-scale defeat by the Indians. Arguably, this hubris contributed significantly to Custer's fall at the Battle of the Little Bighorn.

Ultimately, what Custer's memoir is missing is a sense of genuine justice or mercy. Although he consistently expresses interest in and even respect for various elements of Indian life, the destruction of Indian life remains, in Custer's narrative, inevitable. Of course, as a military officer, he is directly involved in the destruction of Indian life necessitated by Westward expansion and settler colonialism, and he remains, throughout the book and until the day of his ultimate defeat, a willing participant in the destruction of Indian life. While Custer often ruminates on how Indians should be "managed" and expresses a desire for some measure of justice for Indians who have accepted the reservation system, these concerns are extended to only those Indians who have stopped resisting colonization. Custer dedicates an entire chapter of the memoir to an analysis of the Indian Bureau and notes many problems with corrupt agents. Still, in calling for the Indian Bureau to be transferred to the War Department as a way to address corruption, Custer only further reveals his support for state-sponsored assimilation. Custer writes, "At war the Indians are under the control of the military, at peace under the control of the civil officers" (Custer [1874] 1976, p. 174). Any sense of justice or mercy toward Indians remains contingent upon the Indians acquiescing to this control.

The final lines of My Life on the Plains capture the significance of the book from a literary and historical perspective. On the brink of a new expedition that would take him to the sacred Black Hills, 
Custer directly addresses his readers: "Bidding adieu to civilization for the next few months, I also now take leave of my readers, who I trust, in accompanying me through my retrospect, have been enabled to gain a true insight into a cavalryman's 'Life on the Plains'" (Custer [1874] 1976, p. 381). The value in Custer's memoir ultimately lies not in what it purports to reveal about Indian life, but rather in what it reveals about Custer as a cavalryman and aspiring writer. Indeed, My Life on the Plains demonstrates the relationship between war and narrative in that the stories crafted in service of establishing an enemy are often tinged with injustice and an overarching political agenda. Just as Custer's memoir is severely flawed in attempting to depict Indian life from the perspective of the conqueror, dominant historical narratives are often complicit in the same way.

Additionally, My Life on the Plains humanizes Custer-often depicted in popular literature and film as a cartoonish, egomaniacal, knight-errant—as a real and complex individual. Many scholars find Custer a difficult subject to write about, largely due to his status as an agent of colonialism. However, as Cozzens (2016) and Utley and Washburn [1977] (2002) argue, dismissing Custer's perspectives because he was aligned with the conquering forces of colonialism does not contribute to a balanced or comprehensive historical narrative. Stiles (2016) understands Custer as a man of contradictions, and indeed, contradictions are evident in Custer's descriptions of Indians. Stiles explains, "By binding Indians' positive attributes to their savage, hostile state, he preserved his racial scheme-and superiority-without denying the truth of his experiences" (369). Surely, Custer was guilty of countless wrongs and injustices, and his memoir does not counter or mitigate those injustices. Nevertheless, the memoir remains an account from someone who was there, reflecting on and facilitating historical forces whose implications continue to shape American life today. As Mueller (2017) argues, "historical figures should be more than one-dimensional caricatures for modern Americans to use as emotional punching bags." Custer's identity as a military icon ultimately rested on the presence of an enemy from which he needed to distance himself in order for the logic of colonialism to take shape. Yet, Custer was face-to-face with that "enemy" in intimate ways that piqued his curiosity as both soldier and writer; the fact that Custer was an agent of colonialism does not mean that his interest in Indian life was disingenuous. Even within a war narrative clearly rooted in colonial ideology, the simplistic divisions between protagonist and antagonist, hero and enemy, are often unstable. Scholars and students can find value in Custer's memoir not for what it purports to reveal about Indian life, but rather in how it reveals the powerful role of narrative as a defining characteristic of war.

Funding: This research received no external funding.

Conflicts of Interest: The author declares no conflict of interest.

\section{References}

Brown, Dee. 2007. Bury My Heart at Wounded Knee: An Indian History of the American West. With a new foreward by Hampton Sides. New York: St. Martin's. First published 1970.

Callahan, Kathe, Melvin J. Dubnick, and Dorothy Olshfski. 2006. War Narratives: Framing Our Understanding of the War on Terror. Public Administration Review 66: 554-68. [CrossRef]

Cox, Alicia. 2017. "Settler Colonialism". Oxford Bibliographies. Available online: http:/ / www.oxfordbibliographies. com/view/document/ obo-9780190221911/obo-9780190221911-0029.xml (accessed on 6 February 2019).

Cozzens, Peter. 2016. The Earth is Weeping: The Epic Story of the Indian Wars for the AmericanWest. New York: Alfred A. Knopf.

Custer, George Armstrong. 1976. My Life on the Plains, or, Personal Experiences with Indians. Introduction by Edgar I. Stewart. Norman: University of Oklahoma Press. First published 1874.

Dunbar-Ortiz, Roxanne. 2014. An Indigenous Peoples' History of the United States. Boston: Beacon Press.

Kreyche, Gerald F. 1994. The Two Faces of George Armstrong Custer. USA Today 122: 2588.

Loomba, Ania. 2005. Colonialism/Postcolonialism. New York: Routledge. 
Mueller, James E. 2017. Muller on 'A True Insight into a Cavalryman's Life': George Armstrong Custer as Literary Journalist. American Journalism Historians Association. Available online: https:/ /ajha.wildapricot. org/Intelligencer/5288325 (accessed on 6 February 2019).

Stiles, T. J. 2016. Custer's Trials: A Life on the Frontier of a New America. New York: Penguin Random House.

Utley, Robert M., and Wilcomb E. Washburn. 2002. Indian Wars. New York: American Heritage Press. First published 1977.

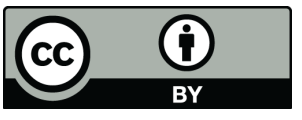

(C) 2019 by the author. Licensee MDPI, Basel, Switzerland. This article is an open access article distributed under the terms and conditions of the Creative Commons Attribution (CC BY) license (http:/ / creativecommons.org/licenses/by/4.0/). 